\title{
Reason and Political Economy in Hume
}

\author{
ERIK W. MATSON \\ New York University
}

\begin{abstract}
This paper examines some connections between Hume's epistemology in his Treatise of Human Nature and his political economy. I make three claims: (1) First, I argue that it is the development of Hume's account of the faculty of reason in Book I of the Treatise that leads him to emphasize social science-including political economyand the humanities over more abstract modes of intellectual inquiry. (2) Second, I argue that Hume's conception of reason has implications for his methodology in political economy. His perception of human reason leads him to deploy a method of qualified generalization that emphasizes the by-and-large nature of theoretical statements. (3) Third, when it comes to policy matters, the method of qualified generalization in theory cashes out in terms of practical maxims. I suggest that two central maxims in Hume's political economy derive from his views of the usefulness of economic liberty and the coordinating nature of the status quo.
\end{abstract}

Keywords: David Hume, political economy, reason, epistemology, methodology

JEL Classification: B12, B31, B40

\section{INTRODUCTION ${ }^{1}$}

In 1739, David Hume published Books I and II of his famous Treatise of Human Nature. A year later he published Book III. The Treatise was illreceived, falling, as Hume put it, "dead-born from the press" (1987,

\footnotetext{
1 Abbreviations: References to the Treatise of Human Nature are to Hume (2007), abbreviated as 'T', followed by book, part, section, and paragraph. References to $A n$ Enquiry Concerning Human Understanding are to Hume (2000), abbreviated as 'EHU', followed by section, part [when one exists], and paragraph. References to An Enquiry Concerning the Principles of Morals are to Hume (1998), followed by section, part [when one exists], and paragraph. References to the Essays, Moral, Political, and Literary are to Hume (1994), abbreviated as 'EMPL', followed by page. References to The History of England are to Hume (1983), followed by volume and page. References to An Essay Concerning Human Understanding are to Locke (1975), followed by book, chapter, and section.
}

AuthoR's NotE: Thanks to Erwin Dekker, Daniel Klein, Thomas Merrill and three anonymous referees for their constructive comments and helpful suggestions. 
xxxiv; italics original). After the disappointing reception of the Treatise Hume moved on to other projects. He became particularly well-known for his contributions to the social sciences and humanities, becoming a recognized authority in matters of morals, politics, political economy, and history. He was perhaps most famous in his day for his celebrated six-volume History of England.

I do not think, as some have argued, that Hume's post-Treatise career and shifting focus towards social science marked an end to his philosophy. ${ }^{2}$ Rather, I consider Hume's post-Treatise developments to be consistent with, and even manifestations of, the philosophical explorations in his original volume. ${ }^{3}$ In the present essay, I seek to elaborate some connections between Hume's early thinking in epistemology and his later developments in political economy. Understanding these connections illustrates Hume's well-developed social outlook and sheds new light on his philosophical approach to economics.

I break down my analysis into three claims. (1) First, I argue that it is the development of Hume's account of the faculty of reason in Book I of the Treatise that leads him to emphasize social science-particularly politics and political economy-and the humanities over more abstract modes of intellectual inquiry. (2) Second, I argue that Hume's conception of reason has implications for his methodology in political economy. His perception of human reason leads him to deploy a method of qualified generalization that emphasizes the by-and-large nature of theoretical

\footnotetext{
${ }^{2}$ In their introductory remarks to Volume 3 of the 1889 edition of The Philosophical Works of David Hume, Grose and Green (1889) comment on Hume's movement from epistemology to social science, speaking of "the suddenness with which [Hume's] labours in philosophy came to an end" (75). Such thinking, although not uncommon among some of Hume's earlier interpreters, overstates the independence of Hume's Treatise and his subsequent works and hinges on an overly narrow conception of Hume's 'philosophy' (see Miller 1987, xviii).

${ }^{3}$ James Harris (2015) surveys the historical development of views on the relationship between Hume's Treatise and his subsequent writings. Harris argues that Hume should not be read as a systematic thinker but as a man of letters with various philosophical interests and projects: "In later life, Hume nowhere described himself as thinking of his works as a unity of any kind at all. Once he had given up on the Treatise, Hume never once presented himself as a systematic thinker, as someone who conceived of his writings in terms of foundation and superstructure, or of core and periphery, or of trunk and branches" (13). I agree with Harris that Hume's corpus should not be read as a completely unified systematic effort. But this does not mean that there is not significant philosophical, methodological, and conceptual continuity between Hume's various projects, or that his post-Treatise works cannot be read as applications of the principles developed in the Treatise. For other similar views see, e.g. Livingston (1984); Miller (1987); Danford (1990); and Merrill (2015). For a slightly different but compatible account, see Immerwahr (1991).
} 
statements. Although we can reason with a high degree of certainty at a general and abstract level, the applicability and relevance of such reasoning to particular matters of fact is much less certain. (3) Third, when it comes to policy matters, the method of qualified generalization in theory cashes out in terms of practical maxims. I suggest that two central maxims in Hume's political economy derive from his views of the usefulness of economic liberty and the coordinating nature of the status quo.

\section{HuME'S ACCOUNT OF REASON}

Hume's account of reason is central to his view of the potentialities of human understanding. ${ }^{4}$ It is also central to his conception of what philosophers should do-a conception that comes to emphasize reflection in light of human action rather than the seeking independent foundations of knowledge. The account develops dialectically throughout Book I of the Treatise by relating two different concepts of reason. Hume begins by formulating and employing a narrow concept of reason largely taken from Locke. He finds that this narrow concept cannot explain the mechanisms of probable reasoning or our ideas about causation. The narrow concept of reason cannot justify or explain our belief in what Don Garrett $(1997,86)$ calls the "Uniformity Thesis", i.e. the proposition that the future will resemble the past (see $\mathrm{T}$ 1.3.6.4). Not wanting to call into question our reliance on experience or the practice of probable reasoning, Hume moves to reconfigure and broaden the faculty of reason. His broader version of reason, which includes probable reasoning, depends upon principles of the imagination by which the mind transitions from past ideas to present impressions. But from the perspective of the narrow version of reason Hume recognizes that it is lacking in epistemological rigor.

The dialectic between the narrow and wide conceptions of reason, and the resulting question of belief and justification, lies close to the heart of Hume's philosophy. The narrow and broad concepts of reason might be said to constitute two "contrarieties of thought which structure [Hume's] drama of inquiry" (Livingston 1984, 35). This drama influences the kind of subjects that become central to Hume's philosophy. Hume's account of reason and its shortcomings leads him

\footnotetext{
${ }^{4}$ For a more developed account of my interpretation of Hume's account of reason and its relation to the secondary literature see Matson (2018). For broadly similar accounts see Winters (1979); Baier (1991); Owen (1999).
} 
to shift his philosophy away from metaphysics and towards more practical matters of social science and humanities.

To begin unpacking this account in Hume's text, it is important to understand that he employs the word 'reason' in two major senses. ${ }^{5}$ Those senses correspond to: (1) the narrow faculty of reason and (2) the broader faculty of reason. I will refer to the narrow faculty of reason as 'reason'. Reason1 is a narrow inferential faculty that operates demonstratively by constructing chains of intuitive ideas. I will refer to the wider faculty of reason as 'reason2'. Reason2 is the broader practical faculty of inference that envelops reason 1 and synthesizes it with the principles of the imagination requisite to explain the mechanisms of probable reasoning (see Owen 1999, 203-204).

Early in Book I of the Treatise Hume almost exclusively confines his use of the word 'reason' to mean reason1. Apart from some passages in the introduction of the work, Hume seems to mean reason1 almost every time he refers to 'reason' (qua faculty) until around T 1.3.11.1. Reason1 corresponds to Locke's concept of demonstrative reasoning. ${ }^{6}$ Demonstrative reasoning in Locke begins with intuitive ideas. Intuition is the mind's "native Faculty to perceive the Coherence, or Incoherence of its Ideas" (ECHU 4.17.2; italics original). Demonstrative reasoning builds on intuitive ideas by intuiting connections between them and other intuitive ideas. A line of demonstrative reasoning thus forms a chain of intuitively-connected intuitive ideas. By Locke's definition, demonstrations show "the Agreement, or Disagreement of two Ideas, by the intervention of one or more Proofs, which have a constant, immutable [i.e. intuitive], and visible connection with one another" (ECHU 4.15.1; italics original).

In illustrating the ideas of intuition and demonstration, Locke gives the example of a triangle (ECHU 4.15.1). We can clearly perceive or intuit the idea of a triangle: a closed figure made up of three straight lines. We can intuit the idea of a right angle as the angle made by perpendicular straight lights. Given the idea of a triangle and a right angle, we can demonstrate-perceive the connection between a number of intuitive, intermediate ideas-that the sum of the angles in a triangle equals the sum of two right angles. Such a demonstration is certain by its

\footnotetext{
${ }^{5}$ It should also be noted that sometimes Hume casually uses "reason" in reference to the general activity of reasoning, i.e. the activity of deliberation and inference associated with "having reasons" for doing things.

${ }^{6}$ For an elaboration of the Lockean character of reason1, see Owen (1999, especially Chapters 3 and 4).
} 
perception and cannot be subject to question unless one incorrectly perceives the ideas of 'triangle', 'right angle', 'straight line', 'closed figure', etc. Demonstrative reasoning thus leads to conclusions that are certain by the law of non-contradiction.

Hume all but explicitly formulates reason1 in a Lockean demonstrative sense within the first passages on the faculty of reason in the Treatise:

A demonstration, if just, admits of no opposite difficulty; and if not just, 'tis a mere sophism, and consequently can never be of difficulty [...] To talk therefore of objections and replies, and ballancing of arguments in such a question as this, is to confess, either that human reason [reason1] is nothing but a play of words, or that the person himself, who talks so, has not a capacity equal to such subjects (T 1.2.2.6).

The limitations of reason 1 become apparent in the Treatise when Hume turns to consider probable reasoning in $\mathrm{T}$ 1.3.6. For Locke, probable reasoning is one of the two modes of the faculty of reason (ECHU 4.17.2). Locke's probable reasoning works on matters of experience by probabilistically inferring from past to present experience-i.e., if $x$ occurred like that in the past, $x$ will, under similar conditions, probably happen like that in the future. Hume similarly conceives of the idea of probable reasoning; but he does not see it to be a matter of reason1.

His own analysis of probable reasoning has both a negative and a positive component. The negative component is simply that probable reasoning is unexplainable by way of reason1: "[P]robable reasoning is not explained by the faculty of reason, traditionally conceived" (Owen 1999, 137). The positive component is Hume's explication of probable reasoning in terms of his new theory of belief. He conceives of probable reasoning as an imagination-dependent activity facilitated by the mental association of ideas through perceived relations of cause and effect, contiguity, and resemblance (T 1.3.9.3).

For probable reasoning to be explainable by reason1, its requisite presupposition (the Uniformity Thesis) would have to be provable by demonstration. Hume is clear that this is not the case:

[I]f reason [reason1] determin'd us [in making the inference from a present impression to the idea of an unobserved object], it wou'd proceed upon that principle, that instances, of which we have had no 
experience, must resemble those, of which we have had experience, and that the course of nature continues always uniformly the same" (T 1.3.6.4; italics original).

The Uniformity Thesis cannot be demonstrated in that we can "at least conceive a change in the course of nature" ( $T$ 1.3.6.5). As Hume says at $\mathrm{T}$ 1.2.2.6, a just demonstration does not entail, and cannot possibly entail, objections or counter arguments. It is impossible, for instance, to dispute the demonstration that a triangle has one-hundred and eighty degrees unless one misapprehends one of the ideas-e.g., 'line' or 'degree'-constitutive of the demonstration. If one can conceive an idea contrary to $x$, then $x$ is non-demonstrable and not reason1reasonable by definition. The very fact that the mind can entertain the idea of, e.g., the sun not rising tomorrow means that the uniformity of experience is not demonstratively certain (see EHU 4.1.2). Hume concludes, "there can be no demonstrative argument to prove, that those instances, of which we have had no experience, resemble those, of which we have had experience" (T 1.3.6.4; italics original). ${ }^{7}$ As every line of probable reasoning logically rests upon the Uniformity Thesis, no line of probable reasoning is provable by demonstration.

Hume recognizes that no one can effectively deny the soundness of probable reasoning in practice. Although the negative component of his argument does raise a "specter of skepticism" that comes to bear in his later reflections (Garrett 1997, 95), he has no interest in dissuading anyone from using probable reasoning, contrary to the interpretations of some of his early critics (Kemp Smith 2005, 22). His point, rather, is that probable reasoning is enabled by a belief-generating operation of the imagination by which ideas are conceived of in "lively" manner "related to or associated with a present impression" (T 1.3.7.5). Put differently, probable reasoning operates within a framework of natural belief or custom that is sustained by the psychological constitution of the imagination. This positive component of Hume's argument comes to head when he claims, "all probable reasoning is nothing but a species of

\footnotetext{
${ }^{7}$ A natural response to this aspect of Hume's analysis might be to invoke probability and say, "the future may not resemble the past with demonstrative certainty, but it surely resembles the past with probability". Yet Hume points out that to invoke probability as a resolution to this problem is assuming that which needs resolving: "[All] our experimental conclusions proceed upon the supposition, that the future will be conformable to the past. To endeavour, therefore, the proof of this last supposition by probable arguments, or arguments regarding existence, must be evidently going in a circle, and taking for granted, which is the very point in question" (EHU 4.1.19).
} 
sensation. "Tis not solely in poetry and music, we must follow our taste and sentiment, but likewise in philosophy" (T 1.3.8.12).

Hume recognizes that within the arena of common life, the grounds of probable reasoning are, in a sense, "entirely free from uncertainty" (T 1.3.11.2; italics original). As such, he broadens his working conception of 'reason' from reason1 to reason2. He signals this semantic transition towards the end of $\mathrm{T} 1.3$ :

Those philosophers [including Locke], who have divided human reason into knowledge and probability, and have defin'd the first to be that evidence, which arises from the comparison of ideas, are oblig'd to comprehend all our arguments from causes or effects under the general term of probability. But tho' every one be free to use his term in what sense he pleases; and accordingly in the precedent part of this discourse, I have follow'd this method of expression; 'tis however certain, that in common discourse we readily affirm, that many arguments from causation exceed probability, and may be receiv'd as a superior kind of evidence ( $\mathrm{T}$ 1.3.11.2; italics original, boldface added).

The emboldened phrase suggests that perhaps Hume has been using 'reason' in the preceding pages of the Treatise 'in what sense he pleases'. He has been using 'reason' in a sense that differs from Locke and 'those philosophers'. That sense is reason1, which differs from Locke's reason (a complex of both demonstrative and probable reasoning) because it excludes probable reasoning (see Millican 1998, 145). But he continues that common sense forcefully tells us that probable reasoning is a superior sort of evidence to other "whimsies and prejudices" of the imagination that probable reasoning at least partially resembles (see $\mathrm{T}$ 1.3.9.19 n22). Hume recognizes that the natural-belief framework of probable reasoning has a high degree of practical merit that takes on a type of certainty within the context of ordinary and scientific life (see De Pierris 2001, 377-380). As such, he considers it to be properly designated as 'reason' (i.e. reason2). ${ }^{8}$

\footnotetext{
${ }^{8}$ In a letter to John Stewart, who attacked Hume for his views on the idea of causation, Hume speaks of different sorts of certainty associated with reason1 and reason2. He says that the certainty that results from reason2 deliberations is more sure than other kinds of certainty, but less sure than the demonstrative kind: "[A]llow me to tell you, that I never asserted so absurd a Proposition as that any thing might arise without $a$ Cause: I only maintain'd, that our Certainty of the Falsehood of that Proposition proceeded neither from intuition nor Demonstration; but from another source. That Caesar existed, that there is such an Island as Sicily; for these Propositions, I affirm, we have no demonstrative nor intuitive Proof. Would you infer that I deny their Truth, or
} 
As a conceptual matter, reason2 simply equals reason1 plus probable reasoning and its facilitating principles of the imagination. As probable reasoning is "a species of sensation" ( $\mathrm{T}$ 1.3.8.12), reason2 is at its core much more a matter of instinct than of strict cognition. Reason2 is "more properly an act of the sensitive, than of the cogitative part of our natures" (T 1.4.1.8; italics original). When Hume gives a definition of 'reason' at the end of Book I, Part 3-which is the first explicit definition of 'reason' in the Treatise-he defines reason2 thus: "To consider the matter aright, reason is nothing but a wonderful and unintelligible instinct in our souls, which carries us along a certain train of ideas, and endows them with particular qualities, according to their particular situations and relations" (T 1.3.16.9). ${ }^{9}$

\section{Hume's PathWAY to Human Things}

Hume's account of reason2 leads him to reorient his philosophy in a way that emphasizes the social sciences and the humanities. This reorientation is a consequence of his conditional acceptance of reason2 as an appropriate concept of 'reason'. Put differently, it turns out that embedded within Hume's formulation of reason2 is a prioritization of human things that puts him on the path to investigate, among other things, political economy. ${ }^{10}$ This comes forth directly in Hume's dramatic and well-known conclusion to Book 1 of the Treatise ( $\mathrm{T}$ 1.4.7; hereafter, 'Conclusion').

Despite the psychological and practical robustness of reason2, it remains unverifiable from the perspective of reason1. Reason2 depends on principles of the imagination that resemble other "whimsies and prejudices" of thought, e.g. superstition (see T 1.3.9.19 n22); it operates within a practical framework of custom and natural belief. As such, the

even their Certainty? There are many different kinds of Certainty; and some of them as satisfactory to the Mind, tho' perhaps not so regular, as the demonstrative kind" (quoted in Mossner 2001, 260).

9 I do not include an interpretation here of Hume's important section, "Of scepticism with regard to reason", which immediately follows Hume's definition of reason2 in T 1.3.16. My basic reading of that section is that after committing to reason 2 in $\mathrm{T} 1.3$, Hume unearths some internal problems with reason2. From the simple observation of fallibility, Hume is led to conclude that demonstrative knowledge turns to probability, and successive probability estimations "continually [diminish] the original evidence" and "utterly subvert all belief and opinion" (T 1.4.1.8; for analysis, see Meeker 2000). This problem figures into the drama of $\mathrm{T}$ 1.4.7 and the difficulties associated with his final commitment to reason2 and philosophy over alternative ways of knowing (see Matson 2018).

${ }^{10}$ For a more extensive interpretation of Hume's path to human things see Merrill (2015, Chapter 2). 
credibility of its applications is not immediately clear. In the Conclusion, Hume reiterates this point, noting that reason2 hinges on "an illusion of the imagination" ( $T$ 1.4.7.6). To corroborate reason2, then, he sees that some standard needs to be developed for discriminating between acceptable and unacceptable illusions of the imagination. If we accept reason2, which hinges on the imagination, on what basis can we discriminate against other phenomena produced by the imagination? We cannot entirely reject the imagination as a source of knowledge-if we do, we cannot rely, among other things, on our experience. Rejection of the imagination would leave "not the lowest degree of evidence in any proposition" ( $\mathrm{T}$ 1.4.7.7). But an open and undiscriminating embrace of the imagination might prove dangerous, leading to wrongheaded thought: "[N]othing is more dangerous to reason than the flights of the imagination, and nothing has been the occasion of more mistakes among philosophers" (T 1.4.7.6).

Hume's dilemma famously leads to a moment of crisis where he exclaims, "I am confounded with all these questions, and being to fancy myself in the most deplorable condition imaginable, inviron'd with the deepest darkness" (T 1.4.7.8). But this despair is not stable. Hume comes out of his crisis through social engagement: "I dine, I play a game of back-gammon, I converse, and am merry with my friends" (T 1.4.7.9). Upon subsequent considerations, although the memory of his melancholy inclines him to abandon philosophy and "throw all [his] books and papers into the fire", his curiosity leads him once more to "seclude [himself] from the commerce and society of men" and engage in philosophical matters (T 1.4.7.9). Despite his reasons for skepticism and his understanding of the problems with reason2, he gravitates back towards philosophy.

He emerges from his personal reflections with a newfound commitment to reason2, albeit a conditional one: "[W]here reason [reason2] is lively, and mixes itself with some propensity, it ought to be assented to. Where it does not, it never can have any title to operate upon us" ( $\mathrm{T}$ 1.4.7.11). His commitment derives both from a sense of public and private usefulness ( $\mathrm{T}$ 1.4.7.10) and general agreeableness ( $\mathrm{T}$ 1.4.7.12). This amounts to what Michael Ridge (2003) has referred to as a moralizing of epistemology (see also Owen 1999, 222). ${ }^{11}$ Although the

\footnotetext{
${ }^{11}$ When Hume later develops his moral philosophy, he argues that moral approval derives from a spectator's view of the complex of a virtue or action's usefulness and agreeableness to the agent and the public.
} 
commitment to reason2 is not based upon a rigorous metaphysics- "we can never have any steady principles, nor any sentiments, which will suit with common practice and experience" (T 1.4.7.14)-Hume views it as conducive to developing "a system or set of opinions, which if not true (for that, perhaps, is too much to be hoped for) might at least be satisfactory to the human mind" ( $\mathrm{T}$ 1.4.7.14). Despite its problems, reason2 is the basis of the most useful interpretive framework.

The nature of Hume's commitment to reason2 leads him to prioritize practical matters of social science and humanities. The fact that he accepts reason 2 on the basis of its apparent usefulness and agreeableness appears to lead him to shift the practical focus of his philosophy to matters of personal and common human interest:

I cannot forbear having a curiosity to be acquainted with the principles of moral good and evil, the nature and foundation of government, and the cause of those several passions and inclinations, which actuate and govern me. I am uneasy to think I approve of one object, and disapprove of another; call one thing beautiful, and another deform'd; decide concerning truth and falshood, reason and folly, without knowing upon what principles I proceed (T 1.4.7.12).

Hume discovers through his own journey that human beings are actuated in their reasoning by fundamentally inexplicable desires and principles in their nature. Instead of working to fully rationalize such principles, which he recognizes will inevitably lead to skepticism, he turns to study the arenas in which they are most directly on display. ${ }^{12}$

It should be noted here that Hume's commitment to reason2 is not a blanket endorsement of common sense. His recognition of the imaginary constitution of reason2 and the practical nature of his own commitment affects not only the subjects to which he feels reason2 can be justly deployed-i.e. morals, politics, the passions, aesthetics, etc.but also the manner of just reasoning about such subjects. He later underlines this in his Enquiry Concerning Human Understanding: "[I]n

\footnotetext{
${ }^{12}$ Merrill (2015) nicely captures the essence of Hume's turn here: "Moral and political topics have pride of place in the inquiries on which Hume now embarks ( $\mathrm{T}$ 1.4.7.12). This is not because Hume regards those opinions as unshakeable or sacrosanct. It is rather because human beings are the moralizing animals. They spontaneously praise and blame, admire and detest, prefer and disdain. Even philosophers who hold their fellows in contempt cannot avoid praising and blaming. Since the self cannot be studied directly as though it were just another object of science, we must look to what human nature does" (59).
} 
general, there is a degree of doubt, and caution, and modesty, which, in all kinds of scrutiny and decision, ought for ever to accompany a just reasoner" (EHU 12.3.1). The nature of reason2 cautions against a dogmatical spirit, even in the realm of practical affairs. Reason2 operates within a framework of custom and upon a sense of practicality; recognizing it as such should lead to a degree of mitigated skepticism in all reasoning (see T 1.4.7.11; EHU 12).

\section{QUALIFIED GENERALIZATION OF POLITICAl ECONOMY}

Hume's account of reason in the Treatise has important implications for his political economy. ${ }^{13}$ At the most basic level, it is his conditional commitment to reason2 that leads him to apply his philosophy to moral, political, and economic (a subset of politics for Hume) matters. ${ }^{14}$ But beyond guiding the general direction of his inquiries, his conception of reason also speaks to his view of the proper method of reasoning in political economy. This view turns out to have both theoretical and practical consequences. On a theoretical level, Hume emphasizes reasoning in political economy in terms of qualified generalizations. At a sufficiently general and abstract level we can reason with a high degree of certainty. But the generalization and abstraction of such reasoning renders its conclusions merely "hypothetical", as John Neville Keynes $(2017,205)$ uses the term in reference to conclusions of his deductive method. The application of generalized reasonings to particular matters of fact introduces degrees of uncertainty. Even conclusions that are certain in the abstract require qualification in application. On a practical level, Hume's qualified theoretical generalizations translate into qualified practical generalizations, or

\footnotetext{
13 Scholars have emphasized other connections between the Treatise and Hume's political economy. Eugene Rotwein (2009) connects Hume's theory of the passions (Treatise Book II) to his economic psychology. Carl Wennerlind (2001) links Hume's analysis of obligation and the utility of promises (Treatise Book III) to his monetary theory. Till Grüne-Yanoff and Edward McClennen (2008) develop a sociological theory of preference change and economic development by drawing on Hume's theory of the passions (Book II). Wennerlind (2011) suggests that Hume's theory of justice as property (Book III) can be adequately understood only in conjunction with his writing on commerce. Margaret Schabas and Wennerlind (2011) draw on the Treatise to argue that Hume accorded economics a higher epistemic status than Newtonian physicswhereas we have no way of observing directly the connecting principle of gravity, Hume thinks we can, by inward reflection, observe causal connections between passions and behaviors.

${ }^{14}$ I hereafter mean 'reason' as reason2 unless otherwise specified.
} 
practical maxims. These maxims function as presumptions around which particular policy discussions can be organized.

The connection of Hume's method of qualified generalization to his account of reason, and to the philosophical framework of the Treatise more generally, appears directly in the beginning of the first essay in his Political Discourses, "Of Commerce": 15

The greater part of mankind may be divided into two classes; that of shallow thinkers, who fall short of the truth; and that of abstruse thinkers, who go beyond it. The latter class are by far the most rare: and I may add, the most valuable. They suggest hints, at least, and start with difficulties, which they want, perhaps, skill to pursue; but which may produce fine discoveries, when handled by men who have a more just way of thinking (EMPL, 253; italics original). ${ }^{16}$

This passage directly parallels a passage from Book I of the Treatise ( $\mathrm{T}$ 1.4.3.9) and the discussion in the first essay of the Enquiry Concerning Human Understanding (EHU 1). All three passages relate to the philosophical drama in $\mathrm{T} 1.4 .7$ discussed in the previous section. The underlying theme is that proper thinking, or what Hume sometimes calls 'true philosophy' requires both (1) a recognition of the shortcomings of common or shallow thinking-i.e. rejecting an unreflective acceptance of the standards of custom and common lifeand (2) a recognition that the thinking employed by the philosopher to disassemble common thinking itself relies on a frame of natural belief and custom. While reason points to many problems with common beliefs and opinions, it is itself a product of beliefs that cannot be independently verified-reason2 is useful and agreeable but epistemologically lacking from the vantage point of reason1. The just reasoner must take both points into account and walk a line between shallow thought, skeptical paralysis, and dogmatism.

\footnotetext{
${ }^{15}$ Hume's Political Discourses are a subset of his Essays, Moral, Political, and Literary. The Political Discourses were first published in 1752. The Political Discourses comprised the most successful volume of Hume's Essays, with a second and third edition published in 1752 and 1754 (see Miller 1987, xi-xviii). The essays within the 1754 edition of Political Discourses are: (1) "Of Commerce"; (2) "Of Refinement in the Arts"; (3) "Of Money"; (4) "Of Interest"; (5) "Of the Balance of Trade"; (6) "Of the Balance of Power"; (7) "Of Taxes"; (8) "Of Public Credit"; (9) "Of some Remarkable Customs"; (10) "Of the Populousness of Ancient Nations"; (11) "Of the Protestant Succession"; and (12) "Idea of a Perfect Commonwealth".

${ }^{16}$ This passage has been referred to by E.C. Mossner (2001) as elucidating Hume's "broad philosophical approach to the problems of economics" (269).
} 
The first implication of Hume's notion of true philosophy for political economy is a matter of posture and epistemic humility. The fact that reason is itself to a large degree a product of custom should limit the enthusiasm of the political economist with respect to political progress and policy reform. This idea informs what Frederick Whelan (1985) calls Hume's "practical conservatism [...] derived from caution prescribed by [his] methodological guidelines for right reasoning" (314). ${ }^{17}$ Hume's practical conservatism interrelates with his practical maxim regarding the coordinating tendencies of status quo arrangements (at least his status quo political arrangements), which I return to below. But the more substantive implications of Hume's conception of true philosophy pertains to the level at which political economic theory should take place. Hume makes two specific claims about this in "Of Commerce": (1) First, there should be a strong presumption of falsehood when theory is used to generate specific predictions about particular matters of fact. (2) Second, just theorizing should operate at a high level and offer general but qualified conclusions.

As to the first claim, Hume says, "there are some cases, I own, where an extraordinary refinement affords a strong presumption of falsehood, and where no reasoning is to be trusted but what is natural and easy" (EMPL 254; see also EMPL 47). The logic of this claim rests in part on Hume's understanding of the philosophical problem with probable reasoning, i.e. the problem of induction, and the psychology of reason. The assumption that the future will resemble the past (the Uniformity Thesis) is not demonstrable yet must be practically committed to in order to reason about matters of fact. But such an understanding undermines the epistemological credibility of specific predictions about matters of fact, a fortiori-since the Uniformity Thesis itself is not demonstrable and all predictions regarding matters of fact rest on the Uniformity Thesis, no predictions are demonstrable. There should, therefore, be a general wariness about reason's ability to predict particular outcomes. Such wariness strengthens when one recognizes that even once the Uniformity Thesis is granted and internalized into reason, it is unlikely on Hume's account that an individual mind will properly interpret matters of fact. The mind organizes its experience set

\footnotetext{
${ }^{17}$ Ironically, Hume is a bit inconsistent on this matter in practice. He notes in the Treatise that "we are apt not only to forget our scepticism, but even our modesty", and sometimes appears to do so himself ( $\mathrm{T}$ 1.4.7.15).
} 
into an interpretive framework on the basis of the perceived relations of contiguity, resemblance, and cause and effect (the settled principles of the imagination that constitute reason). But there is no guarantee that conclusions drawn from this organization will correspond to the truthevery individual's experience is quite limited. The best to hope for then is the formulation of some general efficient causes that explain the constant conjunction of certain classes of experience. Drawing on this logic, Hume concludes that men, in their particular business affairs, when they form "schemes in politics, trade, [or] oeconomy", should stay from specific predictions and "too fine" arguments: "Something is sure to disconcert [their] reasoning, and produce an event different from what [they] expected" (EMPL, 254). Reason, by constitution, would seem unfit to credibly offer specific predictions. Unforeseen consequences, perhaps resulting from unanticipated causal forces, abound.

As to the second claim, Hume says:

But when we reason upon general subjects, one may justly affirm, that our speculations can scarcely ever be too fine, provided they be just; and that the difference between a common man and a man of genius is chiefly seen in the shallowness or depth of the principles upon which they proceed. General reasonings seem intricate, merely because they are general; nor is it easy for the bulk of mankind to distinguish, in a great number of particulars, that common circumstance in which they all agree, or to extract it, pure and unmixed, from the other superfluous circumstances (EMPL, 254; italics original).

As previously mentioned, Hume's arguments here prefigure John Neville Keynes' (2017, Chapter 7) analysis of the "hypothetical" character of conclusions of the deductive method. On Keynes' account, we can justly deduce theoretical economic conclusions from general premises, although the relation of such deductions to particular matters of fact depends on the extent to which assumptions of ceteris paribus hold in practice. Keynes (2017), following J. S. Mill, argues, "all laws of causation may be said to be hypothetical, in so far as they merely assert that given causes will in the absence of counteracting causes produce certain effects" (205; italics original). Hume appears to argue along the same lines in "Of Commerce". The "common circumstances" that he speaks of are causes, which might fail to produce uniform observable effects in practice if they are counterbalanced by "superfluous circumstances" (EMPL, 254). Hume continues to speak of "universal 
propositions, which comprehend under them an infinite number of individuals, and include a whole science in a single theorem" (EMPL, 254). The nature of the applicability of such propositions changes due to the varying of local circumstances and the potential presence of counterbalancing causal forces. But like Keynes, Hume does not conclude from this that general and universal propositions have no bearing on particular matters of fact. Rather, he says that the political economist, at least in theoretical matters, should dwell at a level of sufficiently general analysis precisely because such propositions do come to bear, by and large, on the course of events: "[G]eneral principles, if just and sound, must always prevail in the general course of things, though they may fail in particular cases" (EMPL, 254). Analysis on the basis of general principles comports with Hume's conception of proper thinking so long as the application of those principles is qualified.

The kind of general principles that Hume here has in mind appear to be related to the passions (Rotwein 2009; Schabas and Wennerlind 2011) and the related logic of institutional arrangement. Some of Hume's remarks in "Of Commerce" bear a significant resemblance to his analysis in his famous essay, "That Politics May Be Reduced to a Science", where he argues, "so great is the force of laws, and of particular forms of government, and so little dependence have they on the humours and tempers of men, that consequences almost as general and certain may sometimes be deduced from them, as any which the mathematical sciences afford us" (EMPL, 15; italics added). Note his emphasis here on the general nature of these deduced institutional consequences. His conclusions in political theory dwells at a general level about the by-and-large effects of particular institutional arrangements, which he formulates in terms of political truths. His theoretical method in political economy follows along similar lines. He appears to think that we can have a high degree of certainty regarding general conclusions about the nature of institutional arrangements, derived from an introspective theory of the passions and the principles of human action.

\section{Qualified Generalization in Practice: MaXims of Liberty AND STATUS QUO}

Hume's method of qualified generalization in theoretical matters cashes out in policy in terms of qualified practical generalizations or maxims. 
These maxims are informed by theory and applied to policy in a by-andlarge way that is understood as conducive to the public good (Hume's understood purpose of politics). They can be seen functioning as general presumptions for policy that place a burden of proof on alternative recommendations. As qualified theoretical generalizations might not hold in particular instances, so practical maxims might not always hold in policy; but they are presumptively true, or at least useful, until shown otherwise.

There are two central maxims implicit in Hume that serve as useful lenses through which his political economy can be viewed: the liberty maxim and the status quo maxim. ${ }^{18}$ The liberty maxim is the defeasible presumption that liberty in economic affairs, within a settled framework of political authority, best harmonizes private happiness and public interest. Policy that infringes upon economic freedom and dampens commercial spirit in the name of the public good accordingly bears the burden of proof. The status quo maxim is the defeasible presumption that within a stable political order of relatively free government, ${ }^{19}$ departures from the status quo have discoordinating or destabilizing tendencies. This second maxim is relevant for Hume given his concern with maintaining political stability and constitutional order in the wake of the tumult of seventeenth-century English politics. It is also related to his view of the difficulties of anticipating the consequences of political reform and posture of moderation.

These two maxims are not the only practical maxims one can find in Hume. Qualified theoretical generalization can lead to other maxims in political economy. But the liberty and status quo maxims are useful touchstones in that they capture the overall aim and spirit of Hume's project. The general thrust of his theoretical economic analysis leads him to advance the liberty maxim; the general prudential spirit of his politics, combined with his view of the frailties of reason, leads to the status quo maxim.

\footnotetext{
${ }^{18}$ I take the general concepts of the liberty and status quo maxims and their operation as defeasible presumptions in policy from Klein (2012).

${ }^{19}$ Here is how Hume defines free government: "The government, which, in common appellation, receives the appellation of free, is that which admits of a partition of power among several members, whose united authority is no less, or is commonly greater than that of any monarch; but who, in the usual course of the administration, must act by general and equal laws, that are previously known to all the members and to all the subjects" (EMPL, 40-41).
} 


\section{V.I. The Liberty Maxim}

The backbone of the liberty maxim comes from Hume's spontaneous order sensibilities that are first developed in the Treatise and extend all the way through to his Dialogues Concerning Natural Religion (Hamowy 2005, 46-49). In the Treatise Hume articulates that the various institutions of society, from conventions of property and the rules of justice to language and money, are functions of human nature and cultural evolution-they are not consciously designed or calculated (see Hayek 1963). Hume has some confidence in the robustness of these institutions once they are established, especially property and the rules of justice, in that they are selected for, in an evolutionary sense, on the basis of social usefulness. Property and the rules of justice emerge as individuals within a social group recognize that it is in their own longterm interest to abstain from taking what is conventionally understood as the property of others. The rules of justice rely on self-interest to channel individual's more violent passions and desires into calmer and peaceable pursuits of personal advantage (see Hirschman 1977, 24-26). Hume concludes from such thinking, "after the agreement for fixing and observing of this rule [the distinction of property] there remains little or nothing to be done towards settling a perfect harmony and concord" ( $T$ 3.2.2.12). This is the basic logic of the liberty maxim: within a settled framework of the rules of justice, which are merely the protection of property and enforcement of contract, economic liberty is presumptively most conducive to both private and public good.

Hume builds out the liberty maxim from his early thinking on spontaneous order in the Treatise throughout his Essays. The maxim comes across strongly in the more directly economic essays in the Political Discourses. Indeed, one of the major themes of those essays is the moralizing of commercial spirit upon the view that commercial activity naturally arising from economic liberty leads to human flourishing and happiness (Schabas 2014). Hume leverages theoretical generalizations about the benefits of commerce throughout the essays into generalized policy advice in terms a presumption of liberty.

Immediately after the discussion of qualified theoretical generalization in the introduction to "Of Commerce", Hume implicitly argues for something close to liberty maxim by asserting: (a) the power of the state depends on the commercial activity of its citizens; (b) the happiness of its citizens depends on the power of the state to protect their commercial activity; and (c) therefore both the power of the state 
and happiness of citizens are inextricably linked to flourishing commerce. But he immediately qualifies his theory: "This maxim is true in general; though I cannot forebear thinking, that it may possibly admit of exceptions, and that we often establish it with too little reserve and limitation" (EMPL, 255). It is possible that the interest of the state and the happiness of its citizens might diverge. In some cases, the state might be made more powerful by limiting commercial activity: "[T]here may be some circumstances, where the commerce and riches and luxury of individuals, instead of adding strength to the public, will serve only to thin its armies, and diminish its authority" (EMPL, 255). But Hume's subsequent analysis of the applicability of his maxim in various historical circumstances serves to place the burden of proof on anticommercial economic policy.

The theoretical basis for the liberty maxim strengthens in the subsequent essays. Perhaps the most comprehensive case is made in the second essay of the Discourses, "Of Refinement in the Arts", where Hume develops an optimistic account of what he sees as an "indissoluble chain" between industry, knowledge, and humanity, and good governance (EMPL, 271). Based on his theory of the passions, he sees economic liberty as a centerpiece of individual well-being as it enables and promotes industry and an active life. Industry has positive social effects in that it leads to innovation and refinement in the mechanical arts and sciences. Refinement in the arts and sciences leads to sociability and confers positive externalities on the liberal arts, which jointly lead to progress in the knowledge and practice of virtue. He connects public interest to the chain: "[I]ndustry, knowledge, and humanity, are not advantageous in private life alone: They diffuse their beneficial influence on the public, and render the government as great and flourishing as they make individuals happy and prosperous" (EMPL, 272; italics original). Hume thinks that the whole process will have a positive effect on political spirit and the nature of policy-making, encouraging moderation and the "advantages of humane maxims above rigour and severity" (EMPL, 273).

In "Of Money", "Of Interest", "Of the Balance of Trade", and "Of the Jealousy of Trade", Hume drives home the theoretical basis of the liberty maxim and its policy implications. Among other things, he shows how commercial advantages, absent trade restrictions, are conferred from country to country. He walks through the logic of what is now referred to as the price-specie flow mechanism, which speaks to the 
insignificance of trade balance figures even from a concern with stocks of bullion-outflows of precious metals will lower domestic prices, place upward pressure on exports relative to imports, and attract precious metal inflows. The policy implications of these theories perhaps come forth most directly in "Of the Balance of Trade" where he exclaims against both domestic and international trade restrictions:

From these principles we may learn what judgment we ought to form of those numberless bars, obstructions, and imposts, which all the nations of Europe, and none more than England, have put upon trade [...] Our modern politics [...] adopt a hundred contrivances, which serve no purpose but to check industry, and rob ourselves and our neighbors of the common benefits of art and nature (EMPL, 324).

Interestingly, however, as with his statement of the liberty maxim in "Of Commerce", Hume almost immediately qualifies his assertion, in keeping with the qualified nature of his theoretical reasoning and his moderation in application. He admits that not all taxes on foreign goods are "prejudicial or useless" (EMPL, 324). He offers moderate support for taxes on German linen because he thinks that such support encourages domestic manufacturers; he supports a brandy tax in that it increases the relative demand for rum and supports British colonies. Later, in his History of England, we see a similar statement of the liberty maxim followed by a qualification. The initial formulation, as in "Of the Balance of Trade", is quite direct. He says it should be "the constant rule of the magistrate, except, perhaps in the first introduction of any art [...] to leave the profession to itself, and trust its encouragement to those who reap the benefits of it" $(\mathrm{H}$ 3.135; see also $\mathrm{H}$ 3.78). But in the next paragraph he says that there are, however, some arts and professions that might perhaps call for some kind of regulation or subsidization, particularly when the provision of public goods is concerned. ${ }^{20}$

\section{V.II. The Status Quo Maxim}

The second central practical maxim in Hume is the status quo maxim. The status quo maxim, again, is the defeasible presumption that within a stable political order of free government, departures from the status quo have discoordinating tendencies. Unlike the liberty maxim, the status quo maxim is not directly related to the substance of Hume's

\footnotetext{
${ }^{20}$ He speaks specifically of "finances, armies, fleets, and magistracy", followed by an interesting case for state-sponsored religion (H 3.135).
} 
economic policy recommendations. Rather, it serves as a kind of metaqualification for the application of any theoretical principles or their derived practical maxims. The qualified generalization within the status quo maxim is that existing policies within an established free government are beneficial, regardless of their individual theoretical or practical merit, because they contribute to the established political order. Reforming the status quo bears a burden of proof in that no individual practical improvements in economic policy are worth risking the stability of the polity.

The theoretical basis for this maxim is twofold. First, and most importantly, without a stable framework of political authority, the benefits of economic liberty will not be realized. Second, the mean by which reforms are ascertained-the faculty of reason-is imperfect, prone to misinterpretation and a misapprehension of consequences. This second point relates to the general attitude of epistemic humility implied by Hume's concept of just thinking.

As to the first point, economic policy on Hume's account needs to be considered in the context of its contribution to established political order. The conceptual logic of the liberty maxim and the indissoluble chain of industry, knowledge, humanity, and good governance falls apart without a basic frame of authority. Economic reforms, even liberalizing ones, might have significant discoordinating effects that are potentially harmful to their own cause. The status quo of authority can challenge even the liberty maxim in that individual cases of economic liberalization might weaken the framework of political authority, which in fact threatens liberty itself. Hume directly articulates this point: "[L]iberty is the perfection of civil society; but still authority must be acknowledged essential to its very existence: and in those contests, which so often take place between the one and the other, the latter may, on that account, challenge the preference" (EMPL, 40). That which is inimical to stable, generally liberal, political authority is inimical to liberty in the general course of things. Much like the rules of justice, where we see the usefulness of the whole scheme despite single acts of enforcement that might offend our moral sentiments, we might tolerate established practices that impinge upon direct liberty in that they are somehow integral to the established political order, which is good for liberty on the whole.

Hume's sensibilities on these matters derive in large part from his historical context. In the wake of the political and social turmoil in 
England in the seventeenth century, there was genuine concern among intellectuals that the established political framework upholding and enabling commercial refinement and social progress would decay and lead to social regress (Schabas 2014, 981-983). The concern was not without reason. As late as 1745 , there were violent Jacobite uprisings in Scotland attempting a Stuart restoration. In light of such events, Hume worked to develop an "establishment political philosophy [...] to give the established regime, the Revolution Settlement, the Hanoverian succession, the respectable intellectual foundation which, in the 'fashionable system', it had not got" (Forbes 1975, 91). This so-called establishment political philosophy comes across clearly in the Discourses, especially in the essay "Of the Protestant Succession", which is explicitly concerned with philosophical justifications of the political legitimacy of the Hanovers in light of the revolution of 1688.

There are a number of examples throughout Hume's work of him expressing some sympathies for theoretically poor status quo economic and political arrangements on account of their contribution to political stability. In the History of England, in his treatment of the parliamentary remonstrance against the prerogative of Charles I, he notes a list of political and economic abuses, including: "The forced loans: The illegal confinement of men for not obeying illegal commands: The violent dissolution of four parliaments: The arbitrary government which always succeeded: The questioning, the fining, and imprisoning of members for their conduct in the house: The levying of taxes without consent of the commons" (H 5.351). But despite his understanding of the harmfulness of these policies, and the fact that they resulted from crown prerogative, he sympathizes with the royalist position that prerogative should not be fully restricted. The reason for his sympathies is that he understands that restricting authority might, in some cases, lead to populist enthusiasm and animus against political authority, which could, in certain circumstances, have bad consequences for liberty (which it did, at least in the short run, with the execution of Charles I and the rise of Cromwell). From these reflections he draws a general conclusion:

To prevent such an evil, no expedient is more proper, than to contain ourselves within the bounds of moderation, and to consider, that all extremes, naturally and infallibly, beget each other. In the same manner, past usurpations of the crown, however excusable on account of the necessity or provocations whence they arose, have excited an immeasurable appetite for liberty; let us beware, lest our 
encroachments, by introducing anarchy, make the people seek shelter under the peaceable and despotic rule of a monarch $(\mathrm{H}$ 5.356). ${ }^{21}$

A policy that seems theoretically sound, for instance a restriction of arbitrary economic power of the sovereign, might go awry in practice and subvert its own aims. Restricting a degree of arbitrariness (in some contexts) might excite enthusiasm against political authority in general, which could degenerate into chaos and crisis, subverting the framework in which economic liberty and commercial activity subsists.

The second basis for the status quo maxim pertains directly to Hume's account of reason. His reflective commitment to reason despite its shortcomings in the Treatise motivates epistemic humility and moderation. Simply put, we should be hesitant and reserved about the potentialities and capabilities of reason given a basic understanding of its fallibility. As Hume argues, "we must, therefore, in every reasoning form a new judgment, as a check or controul on our first judgement or belief" (T 1.4.1.1). Such checking is particularly important in political matters given their complexity - "political questions are infinitely complicated" (EMPL, 507) - and importance for coordinating social affairs. Hume sees political orders, at least the English political order, as emerging haphazardly, as a consequence of the unintended and unforeseen effects of various historical accidents. The essential and contributory elements of the political order are therefore difficult to disentangle, rendering the art of predicting effects of particular policy reforms on the polity as a whole to be tenuous at best.

\section{V.III. Liberty and Status Quo in Conversation}

Before concluding, a few brief general comments on the practical relationship between the liberty maxim and the status quo maxim are in order. $^{22}$ Both maxims in Hume derive from qualified theoretical generalizations, the liberty maxim from a theory of spontaneous order and the usefulness of economic liberty, the status quo maxim from a

\footnotetext{
${ }^{21}$ Hume articulates a similar logic at H 1.169 where he contrasts the "seeming liberty or rather licentiousness of the Anglo-Saxons" with "true liberty". These general sensibilities are echoed in his attitude towards the radical populist "Wilkes and Liberty" movement in his own time (Raynor 1980). For an elaboration of Hume's conception of "true liberty" and its relation to political authority, see Klein and Matson (forthcoming).

${ }^{22}$ For a comment on the relation and cases of tension between liberty and status quo, see Klein $(2012,255)$.
} 
theory of the coordinating nature of established political order. Both maxims are therefore defeasible: they are presumptions that locate the burden of proof but that can be overturned should that burden of proof be met. But what happens if they conflict and place burdens of proof in the opposite direction?

In any given economic policy deliberation, there are two possible relations between liberty and status quo. First, they might be in agreement and jointly place the burden of proof on the proposed reform. This will be the case in instances where a proposed policy would depart from the status quo arrangement and impinge upon liberty. Proposals of this type, e.g. economic interventions, trade obstructions, etc., would bear a significant burden of proof from a Humean perspective in that they simultaneously run the gambit of dampening the benefits of commerce and destabilizing the political order. In other words, both the liberty and status quo maxims tell against them. Second, a policy proposal might be recommended on the basis of the liberty maxim but run counter to the status quo maxim. This will be the case in instances of policy liberalization, e.g., removing trade barriers, industry supports, usury caps, etc. The individual logic of such situations will vary. But we can perhaps conclude that the maxim that prevails, i.e. places the burden of proof, will depend upon the degree and continuity of political order. In a context such as Hume's, where the established political framework is relatively new, it may well be the case that the status quo maxim overturns the liberty maxim for a time, placing the burden of proof upon liberalization efforts. In such cases, the preservation of the burgeoning political order will be more important, and in the long-run more liberalizing, than any individual liberalization efforts. In more established and stable political orders, however, the liberty maxim will likely overturn the logic of status quo, shifting the burden of proof towards those who would defend illiberal status quo arrangements.

The more general point, however, is that there is no algorithm or hard-and-fast rule for resolving conflicts between liberty and status quo, nor for determining whether or not a burden of proof has been sufficiently met to overturn either of the standalone presumptions. Such deliberations will often be matters of taste, as Hume might put it. This is not to say that they are arbitrary and subjective, but rather that discernment in particular instances will depend on one's practice, education, and exposure to history. Hume would say that judgment in 
policy deliberation is a philosophical art one learns by doing (see EMPL, 507). The liberty maxim and the status quo maxim serve as important touchstones for policy discourse, but underdetermine what is good and bad economic policy in particular contexts.

\section{CONCLUSION}

I have argued in this essay that there are important connections between Hume's early work in epistemology and his later writings in political economy. Hume's dialectical account of the faculty of reason in Book I of his Treatise leads him to skepticism, which is resolved by a conditional commitment to reason so long as it is applied to things that appear useful and agreeable from the vantage point of social life. Among such things, morals, politics, and economics loom large. Apart from prompting him to direct reason to human things, Hume's account of reason turns out to have methodological implications for his political economy, as is made clear in the introduction to his essay, "Of Commerce". Hume's views on the imperfections of reason lead him to deploy a theoretical method of qualified generalization in his political economy, which cashes out in matters of policy in terms of practical maxims. Two central practical maxims one can see in Hume's political economy are the liberty maxim and the status quo maxim, which relate to his view of the benefits of economic liberty and the coordinating tendencies of status quo arrangements insofar as they contribute to political stability.

As an historical matter, this account of Hume portrays him, if not as an entirely systematic thinker, as a thinker with significant methodological continuities across important and influential strands of his thinking. It seems not to be the case that Hume abandoned philosophy after the Treatise, but rather that he envisioned a proper application of philosophy, given his epistemological explorations in that volume, to pertain to social sciences and humanities-things naturally of interest and importance from the vantage of common life. As a more philosophical matter, understanding connections between Hume's epistemology and his method of qualified generalization opens the way for further case studies into the merits and limits of qualified theoretical reasoning and practical maxims in political economy, both on their own terms and in relation to the methodological contributions of thinkers after Hume. 


\section{REFERENCES}

Baier, Annette C. 1991. A Progress of Sentiments: Reflections on Hume's Treatise. Cambridge, MA: Harvard University Press.

Danford, John W. 1990. David Hume and the Problem of Reason: Recovering the Human Sciences. New Haven, CT: Yale University Press.

De Pierris, Graciela. 2001. "Hume's Pyrrhonian Skepticism and the Belief in Causal Laws." Journal of the History of Philosophy 39 (3): 351-383.

Forbes, Duncan. 1975. Hume's Philosophical Politics. London: Cambridge University Press.

Garrett, Don. 1997. Cognition and Commitment in Hume's Philosophy. Oxford: Oxford University Press.

Grose, T. H., and T. H. Green. 1889. "History of the Editions." In The Philosophical Works of David Hume, by David Hume, edited by T. H. Grose and T. H. Green, 1584. Vol. 3. London: Longmans, Green and Co.

Grüne-Yanoff, Till, and Edward F. McClennen. 2008. "Hume’s Framework for a Natural History of the Passions." In David Hume's Political Economy, edited by Carl Wennerlind and Margaret Schabas, 86-104. New York, NY: Routledge.

Hamowy, Ronald. 2005. The Political Sociology of Freedom. Northhampton: Edward Elgar.

Harris, James A. 2015. Hume: An Intellectual Biography. New York, NY: Cambridge University Press.

Hayek, F. A. 1963. "The Legal and Political Philosophy of David Hume." Il Politico 28 (4): 691-721.

Hirschman, Albert O. 1977. The Passions and the Interests: Political Arguments for Capitalism before Its Triumph. Princeton, NJ: Princeton University Press.

Hume, David. 1983. The History of England from the Invasion of Julius Caesar to the Revolution in 1688. Edited by W.B. Todd. 6 vols. Indianapolis, IN: Liberty Fund.

Hume, David. 1987. "Of My Own Life." In Essays, Moral, Political, and Literary, edited by Eugene F. Miller, xxxi-xli. Indianapolis, IN: Liberty Fund.

Hume, David. 1994. Essays, Moral, Political, and Literary. Edited by Eugene F. Miller. Indianapolis, IN: Liberty Fund.

Hume, David. 1998. An Enquiry Concerning the Principles of Morals. Edited by Tom L. Beauchamp. Oxford: Clarendon Press.

Hume, David. 2000. An Enquiry Concerning Human Understanding. Edited by Tom L. Beauchamp. Oxford: Clarendon Press.

Hume, David. 2007. A Treatise of Human Nature. Edited by David F. Norton and Mary J. Norton. 2 vols. Oxford: Oxford University Press.

Immerwahr, John. 1991. "The Anatomist and the Painter: The Continuity of Hume's Treatise and Essays." Hume Studies 17 (1): 1-14.

Kemp Smith, Norman. 2005. The Philosophy of David Hume: A Critical Study of Its Origins and Central Doctrines. $2^{\text {nd }}$ ed. New York, NY: Palgrave Macmillan.

Keynes, John Neville. 2017. The Scope and Method of Political Economy. London and New York, NY: Routledge.

Klein, Daniel B. 2012. Knowledge and Coordination: A Liberal Interpretation. New York, NY: Oxford University Press. 
Klein, Daniel B., and Erik W. Matson. Forthcoming. "Mere-Liberty in David Hume." In $A$ Companion to Hume (Universidad Fransico Marroquin); GMU Working Paper in Economics No. 18-14.

Livingston, Donald. 1984. Hume's Philosophy of Common Life. Chicago, IL: University of Chicago Press.

Locke, John. 1975. An Essay Concerning Human Understanding. Edited by Peter H. Nidditch. Oxford: Clarendon Press.

Matson, Erik W. 2018. "The Dual Account of Reason and the Spirit of Philosophy in Hume's Treatise." GMU Working Paper in Economics No. 17-50.

Meeker, Kevin. 2000. "Hume's Iterative Probability Argument: A Pernicious Reductio." Journal of the History of Philosophy 38 (2): 221-238.

Merrill, Thomas W. 2015. Hume and the Politics of Enlightenment. New York, NY: Cambridge University Press.

Miller, Eugene F. 1987. "Foreword." In Essays, Moral, Political, and Literary, by David Hume, edited by Eugene F. Miller, xi-xviii. Indianapolis, IN: Liberty Fund.

Millican, Peter. 1998. "Hume on Reason and Induction: Epistemology or Cognitive Science?" Hume Studies 24 (1): 141-159.

Mossner, Ernest Campbell. 2001. The Life of David Hume. $2^{\text {nd }}$ ed. Oxford: Clarendon Press.

Owen, David. 1999. Hume's Reason. Oxford: Oxford University Press.

Raynor, David R. 1980. "Hume on Wilkes and Liberty: Two Possible Contributions to the London Chronicle." Eighteenth Century Studies 13 (4): 365-376.

Ridge, Michael. 2003. "Epistemology Moralized: David Hume's Practical Epistemology." Hume Studies 29 (2): 165-204.

Rotwein, Eugene. 2009. "Introduction." In Writings on Economics, by David Hume, edited by Eugene Rotwein, xxv-cxi. New Brunswick: Transaction Publishers.

Schabas, Margaret. 2014. “Let Your Science Be Human': David Hume and the Honourable Merchant.” European Journal of Economic History 21 (6): 977-990.

Schabas, Margaret, and Carl Wennerlind. 2011. "Hume on Money, Commerce, and the Science of Economics." Journal of Economic Perspectives 25 (3): 217-230.

Wennerlind, Carl. 2001. "The Link between David Hume's 'Treatise of Human Nature' and His Fiduciary Theory of Money." History of Political Economy 33 (1): 139-160.

Wennerlind, Carl. 2011. "The Role of Political Economy in Hume's Moral Philosophy." Hume Studies 37 (1): 43-64.

Whelan, Frederick G. 1985. Order and Artifice in Hume's Political Philosophy. Princeton, NJ: Princeton University Press.

Winters, Barbara. 1979. "Hume on Reason.” Hume Studies 5 (1): 20-35.

Erik W. Matson is a Postdoctoral Fellow at New York University, Department of Economics. He studies the history and philosophy of economic thought, focusing on David Hume and Adam Smith. Some of his recent work has been published in History of European Ideas, The Adam Smith Review, and the Journal of Scottish Philosophy. Contact e-mail: <ewmatson@gmail.com> 